
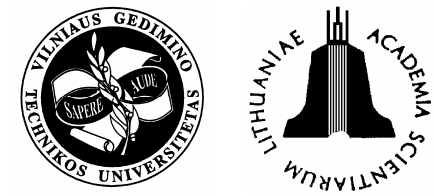

\title{
MATHEMATICAL-NEURAL MODEL FOR ASSESSING PRODUCTIVITY OF EARTHMOVING MACHINERY
}

\author{
Krzysztof Schabowicz ${ }^{1}$, Bozena Hola \\ Institute of Building Engineering, Wrocław University of Technology, Wybrzeże Wyspiańskiego 27, \\ 50-370 Wrocław, Poland. E-mail: ${ }^{1}$ schabowicz@yahoo.com \\ Received 17 March 2006; accepted 26 Sept 2006
}

\begin{abstract}
Many construction processes are carried out by machines working together and forming technological systems, eg earthmoving machinery made up of excavators and haulers (trucks). Productivity $\left(W_{(N)}\right)$ is a key to valuate the process design purposes. The paper presents the results obtained by applying artificial neural networks to predict productivity $\left(W_{(N), S}\right)$ for earthmoving machinery systems, consisting of $c$ excavators and $N$ haulers. Experimentally determined productivity values can form a standard basis for designing construction earthworks. Possessing the data set consisting of the technical parameters of earthmoving machinery systems and the corresponding productivities for different output hauling distances, one can train artificial neural networks and use subsequently for the reliable prediction of $W_{(N), S}$.
\end{abstract}

Keywords: earthwork, productivity, neural networks, queuing theory, systems of collaborating construction machines, construction industry.

\section{Introduction}

The interaction between machines in most sets of earthmoving machinery consisting of excavators and haulers (trucks), found on construction sites, can be analysed from a systemic perspective, using the queuing theory [1-3]. A systemic analysis of the construction processes allows one to assess their productivity, taking into account the probabilistic nature of cycle time determined by time studies.

The analytical solutions of the queuing system models are relatively simple when the latter are single-phase models (with one or many service channels), the flow of arrivals is of the Poisson type and the distribution of service durations is exponential or of the Erlang type [4-6]. In order to use such models one needs to have a proper software capable of performing a large number of computations in a short time for different configurations of machines operating in a system. If, however, the distribution of service times and interarrival times is an arbitrary distribution, single-phase models are solved by simulation methods $[4,7]$. In the latter case, the computer program simulating the system's operation is much more complicated and the computation time is much longer.

The introduction of new sets of machinery or the realization of the works in different environmental conditions makes it necessary (for both the analytical model and the simulation model) to carry out new laborious studies of input and service times. This may pose a problem, since it is often impossible to carry out such studies at the work design stage.

In this paper artificial neural networks (ANN) are applied to design sets of earthmoving machinery. The results of applying ANN to predict productivity $W_{(N), S}$ of systems of collaborating earthmoving machines, consisting of $c$ excavators and $N$ haulers, are presented.

\section{Research methodology}

The methodology schematically shown in Fig 1 was used to demonstrate the usefulness of artificial neural networks for identifying productivity $W_{(N), S}$ of earthmoving machinery systems.

As Fig 1 shows, the research consisted of two main stages. Stage I covered an analysis of an earthmoving machinery system, made up of $c$ excavators and $N$ haulers, as a mass service system (MSS). Hauler capacity $P_{j t}$, excavator bucket capacity $b_{k}$, output hauling distance $L$, road category $K_{d}$, number of excavators $c$ and number of haulers $N$ operating in the system were the input parameters for this stage which included:

- studies of loading times and hauling cycle times,

- statistical processing of the time study results,

- identification of the process as a queuing system,

- construction of a computer simulator,

- computations which yielded system productivities $W_{(N), S}$.

A single-phase, multichannel mass service system $(M S S)$ with an exponential distribution $(M)$ of interarrival times in the input process, an exponential distribution $(M)$ of service times, a closed cycle of arrivals and FIFO (first in, first out) processing was adopted as the model of the system of collaborating machines. The number of arrivals in the system is limited to $N$ and the number of queuing stations is limited to $c$, where $c<N$. $\lambda$ is an arrivals entry distribution parameter and $\mu$ is a service time parameter. A scheme of the considered system is shown in Fig 2. 


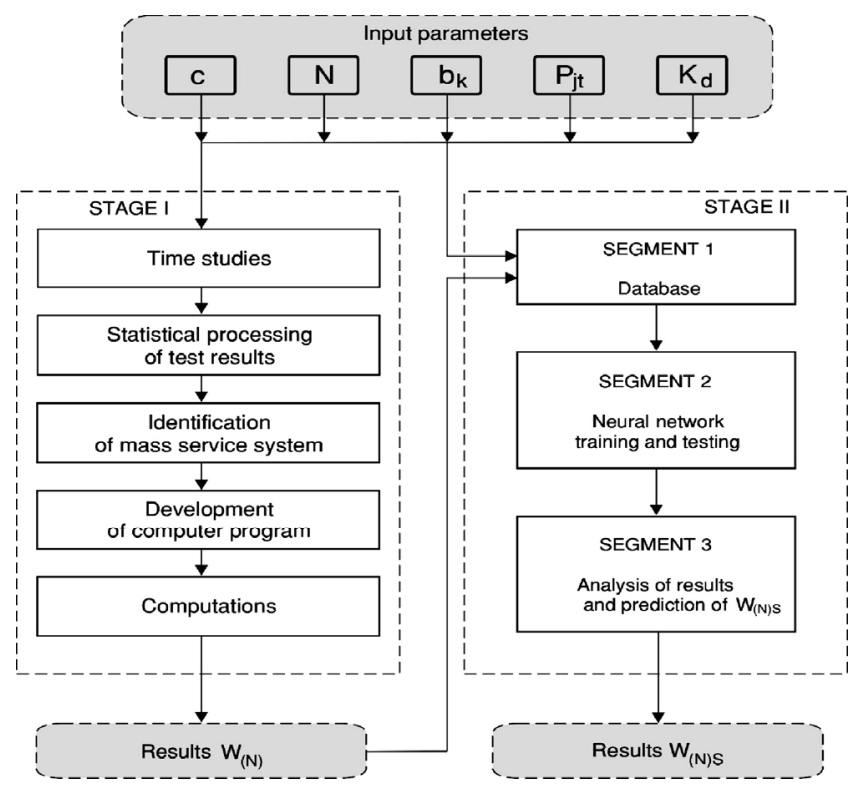

Fig 1. Schema of research methodology

MSS: M/M/c/FIFO/N is the adopted mass service system (queuing system) code (1).

Such a queuing system (QS) can be analysed by the theory of discrete random processes [1]. A random stochastic process is a family of the following random variables:

$$
\left\{S_{t} ; t \in T\right\}=\left\{S_{t}\right\}_{t}
$$

where $t$ assumes values from set $T$, and $S_{t}$ is the state of QS at instant $t$.

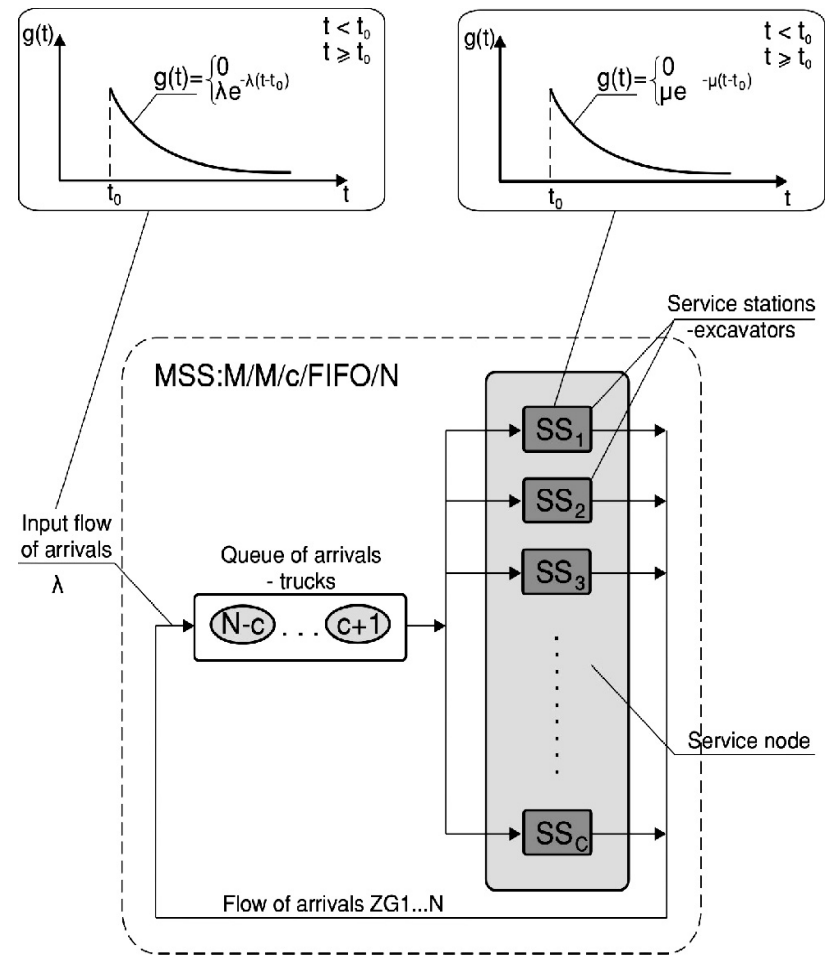

Fig 2. Diagram of mass service system considered
The considered system can be in the following states:

$S_{0}$ - there are no arrivals in the system;

$S_{l}$ - there is one arrival in the system, which is being serviced; $k<c$;

$S_{k}$ - there are $k$ arrivals being serviced in the system,

$S_{c}$ - there are $c$ arrivals in the system, all of them being serviced;

$S_{c+r}$ - there are $c+r$ arrivals in the system, $c$ arrivals are being serviced, $r$ arrivals are queuing;

$S_{N}$ - there are $N$ arrivals, $c$ arrivals are being serviced, $N-c$ are waiting for service.

It is apparent that the number of states which the considered QS can reach is finite. A graph of permissible states is shown in Fig 3.

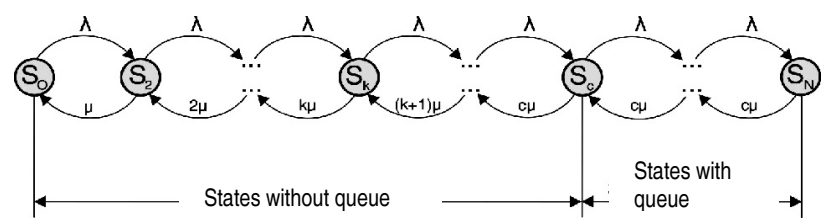

Fig 3. Graph of states for queuing system $\mathrm{M} / \mathrm{M} / \mathrm{c} / \mathrm{FIFO} / \mathrm{N}$

Symbol $\lambda$ or $k \mu ; k=1, \ldots ., c$, which stands for the probability of transition from state $S_{i}$ to state $S_{i+1}$ or to state $S_{i-1}$, is placed over each edge of the graph. At any instant $t_{i}$ the system can be in one of the above-mentioned states. By analysing the possible system states and the probability of reaching them in successive instants $t_{i}$ of system operation one can arrive at the solution of system productivities.

The probability of the QS states can be described by a system of Chapman-Kolmogorov differential equations [1]. For the considered QS the system of equations is:

$$
\left\{\begin{array}{l}
p_{0}^{\prime}(t)=-\lambda p_{0}(t)+\mu p_{1}(t) \\
p_{0}^{\prime}(t)=\lambda p_{0}(t)-(\lambda+\mu) p_{1}(t)+2 \mu p_{2}(t) \\
p_{0}^{\prime}(t)=\lambda p_{k-1}(t)-(\lambda+k \mu) p_{k 1}(t)+(k+1) \mu p_{k+1}(t), 1 \leq k \leq c-1 \\
p_{0}^{\prime}(t)=\lambda p_{c-1}(t)-(\lambda+c \mu) p_{c}(t)+c \mu p_{c+1}(t) \\
p_{0}^{\prime}(t)=\lambda p_{c+r-1}(t)-(\lambda+c \mu) p_{c+r}(t)+c \mu p_{c+r+1}(t), c \leq r \leq N-1 \\
p_{0}^{\prime}(t)=\lambda p_{N-1}(t)+c \mu p_{N}(t)
\end{array}\right.
$$

The initial conditions are defined by the initial position of QS. It was assumed that at the initial instant $t=0$ (system startup) the system was in position $S_{0}$, thus:

$$
p_{0}(0)=1, p_{i}(0)=0, i=1 \ldots \ldots \ldots . . . .
$$

When the system is in a steady state, limit z $t \rightarrow \infty$ is approached and the system of differential equations becomes a system of algebraic equations.

The probability that the considered QS will be in a given state can be calculated from the following system of algebraic equations: 


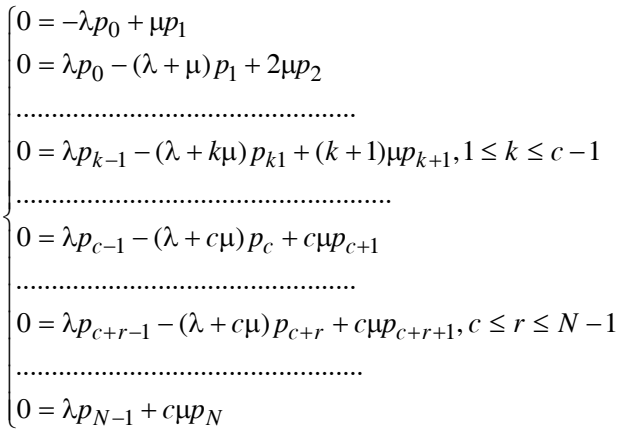

In the steady state the normalising condition has this form:

$$
\sum_{i=0}^{N} p_{i}(t)=1, i=0,1, \ldots, c, \ldots c+r, \ldots, N .
$$

The probabilities of the particular system states will be obtained by solving the above system of equations and using the normalising condition.

$$
\begin{gathered}
p_{0}=\left[\sum_{k=0}^{c} \frac{N !}{k !(N-k) !} \rho^{k}+\sum_{k=c+1}^{N} \frac{N !}{c^{k-c} c(N-k) !} \rho^{k}\right]^{-1}, \rho=\frac{\lambda}{\mu} \\
p_{k}=\frac{N !}{k !(N-k) !} \rho^{k} p_{0}, 1<k \leq c
\end{gathered}
$$

System productivity $W_{(N)}$, defined as the volume of output disposed of in a unit time, is essential for process design needs. The productivity of the system shown in Fig 2 depends on the service channel utilisation coefficient which is expressed by:

$$
W_{(N)}=c\left(1-W P_{(A)}\right) \mu P_{j t},
$$

where: $\mu$ - the average rate of service, $P_{j t}$ - hauler capacity, $c$ - the number of service channels (excavators), $W P_{(A)}-$ a service channel downtime coefficient.

The service channel downtime coefficient is expressed by:

$$
W P_{(A)}=\sum_{k=0}^{k=c-1} p_{(k)}-\frac{1}{c} \sum_{k=0}^{k=c-1} k p_{(k)} .
$$

Using the above mass system service model and the results of studies of hauling cycle times and loading times carried out during massive earthworks, the productivities of different sets of earthmoving machines were calculated.

Stage II covered the construction of an artificial neural network, its training and testing and an analysis of the results. In order to design a system of ANNs for a particular task one needs to specify the network structure, ie determine the number of layers and the number of neurons in each layer, the parameter weights and the activation function coefficients.

A database made up of the technical parameters of the machinery systems (for which time studies had been carried out and productivities $W_{(N)}$ determined from relations 10), calculated by a computer programme simulating the operation of a single-phase, multichannel queuing system, was used to train the network. The database was divided into 5 sets. The division criterion was output hauling distance which amounted to: 1, 2, 3, 5 and $7 \mathrm{~km}$. The data sets were written to a computer file (constituting segment 1 of stage II) and then entered as input parame- ters for the neural networks into segment 2. Each data set was divided into 2 parts: a training set and a testing set.

Segment 2 of stage II (Fig 1) is the MATLAB software used for network simulations. A neural network type was chosen and a neural network with an experimentally determined structure was designed. The training patterns were fed randomly. The neural network training and testing results, including the network structure and the weight values, were saved to a file. The output data from segment 2 were analysed in segment 3 (Fig 1). Two pairs of data were input into the latter segment: one pair was the data from segment 2, yielded by the trained neural network, while the other one were the values from the programme simulating MSS operation. First the data which the neural network had been trained on were input and the ability to reproduce the training patterns was tested. Then the testing data were input and the identification was checked for correctness. The identified productivity $W_{(N), S}$ was obtained at the segment's output.

\section{Artificial neural network}

The productivity of a mass service system depends on many technical parameters of its components and on the operating conditions. The main factors having a bearing on the system's productivity include: hauler loading time, hauler work cycle time, excavator bucket capacity, hauler loading platform capacity, hauler driving speed, excavator bucket working speed, the kind of road surface, the category of the soil, the number of excavators working in the system, the number of haulers working in the system, the excavator work cost and the hauler work cost.

Some of the input parameters were eliminated during the training process in order to obtain an optimal result.

As neural networks are trained, it is analysed how the particular input parameters affect the correctness of the obtained results. As a result of such an analysis, the number of input parameters was reduced to the ones which most affected the correctness of data mapping.

Ultimately, to train the neural network we adopted the following vectors:

$$
W_{(N), S}=\left\{c, N, b_{k}, P_{j t}, K_{d}\right\},
$$

where: $c$ - the number of excavators, $N$ - the number of haulers, $b_{k}$, excavator bucket capacity, $P_{j t}-$ hauler loading platform capacity, $K_{d}$ - the kind of road surface.

As a result of training and testing, a network consisting of 3 unidirectional multilayer error back propagation networks with a conjugate gradient algorithm (BPNNCGB) was constructed (Fig 4). This type of network was chosen since it is most suitable for solving the considered problem [8-23]. A nonlinear sigmoidal activation function was adopted.

Table 1 shows exemplary values of the technical parameters of the machinery systems for which the time studies were carried out and the corresponding productivities yielded by the model simulating the collaboration of the machines. The values were used to predict productivity $W_{(N), S}$, for a hauling distance of $2 \mathrm{~km}$. The structural components of the adopted BPNN-CGB neural network 
are shown in Table 2. The network structure was used then to identify $W_{(N), S}$ for other hauling distances.

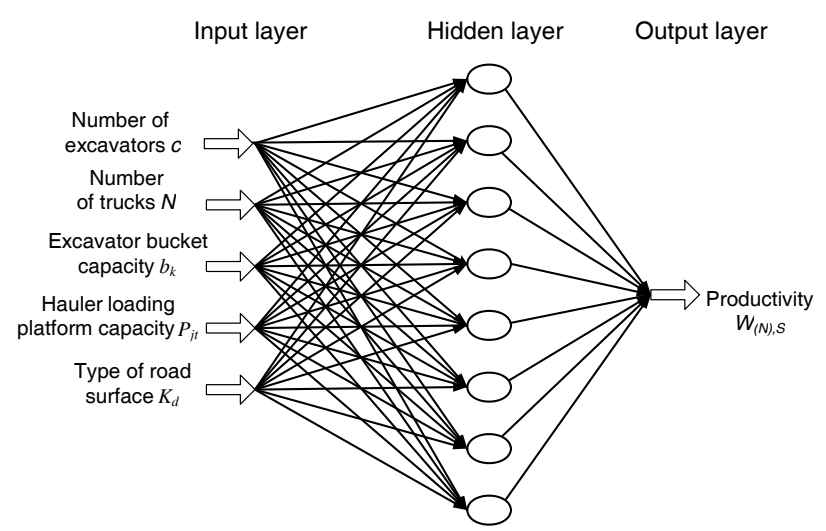

Fig 4. Structure of adopted unidirectional multilayer error backpropagation network with a conjugate gradient algorithm (BPNN-CGB)

The error backpropagation algorithm is considered to be the primary algorithm for training multilayer neural networks [8, 9]. The algorithm consists in modifying the weights on the connections between the neurons of adjacent layers, uses gradient optimisation methods and is based on the minimisation of the sum square of learning errors $[8,9]$.

A set of training patterns can be described as follows:

$$
\begin{aligned}
& x=\left(x_{0}, x_{1}, \ldots, x_{N}\right), \\
& y=\left(y_{1}, y_{2}, \ldots, y_{M}\right), \\
& z=\left(z_{1}, z_{2}, \ldots, z_{M}\right),
\end{aligned}
$$

where: $x$ - an input network vector, $y-$ the current network vector, $z-$ an assigned output network vector, $x_{0}-\mathrm{a}$ unit polarisation vector, $x_{0}=1$ (bias).

\begin{tabular}{|c|c|c|c|c|c|c|}
\hline No & 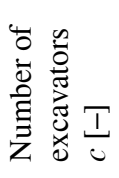 & 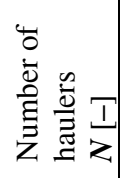 & 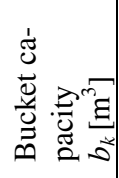 & 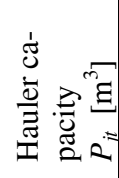 & 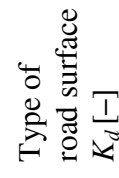 & 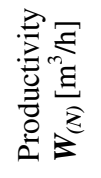 \\
\hline 1 & 2 & 6 & 2,5 & 12 & 2 & 133,33 \\
\hline 2 & 3 & 38 & 2,5 & 12 & 2 & 392 \\
\hline 3 & 4 & 21 & 2,5 & 12 & 2 & 232,36 \\
\hline 4 & 4 & 7 & 3,4 & 12 & 2 & 69,43 \\
\hline 5 & 4 & 22 & 3,4 & 12 & 2 & 179,76 \\
\hline 6 & 4 & 25 & 3,4 & 12 & 2 & 185,25 \\
\hline 7 & 4 & 8 & 5,6 & 10 & 2 & 64,28 \\
\hline 8 & 4 & 16 & 5,6 & 10 & 2 & 128,2 \\
\hline 9 & 4 & 50 & 5,6 & 10 & 2 & 299,01 \\
\hline 10 & 2 & 2 & 5,6 & 12 & 2 & 42,89 \\
\hline 11 & 2 & 4 & 5,6 & 12 & 2 & 85,36 \\
\hline 12 & 2 & 14 & 5,6 & 12 & 2 & 254,78 \\
\hline . & . & & : & . & . & : \\
\hline 200 & 2 & 17 & 5,6 & 12 & 2 & 276,73 \\
\hline
\end{tabular}

Table 1. Exemplary values of parameters for predicting productivity $W_{(N), S}$ for hauling distance of $2 \mathrm{~km}$
Table 2. Adopted structural components of BPNN-CGB neural

\begin{tabular}{|c|c|c|c|c|c|}
\hline \multirow[b]{2}{*}{ 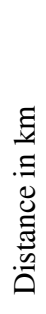 } & \multicolumn{5}{|c|}{ Network structural components } \\
\hline & 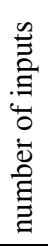 & 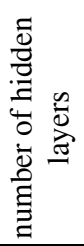 & 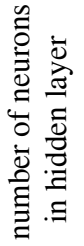 & 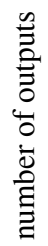 & 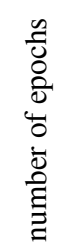 \\
\hline 1 & 5 & 1 & 8 & 1 & 200 \\
\hline 2 & 5 & 1 & 8 & 1 & 200 \\
\hline 3 & 5 & 1 & 8 & 1 & 200 \\
\hline 5 & 5 & 1 & 8 & 1 & 200 \\
\hline 7 & 5 & 1 & 8 & 1 & 200 \\
\hline
\end{tabular}
network for identifying productivity $W_{(N), S}$ for specified hauling distances

A model of the error backpropagation, unidirectional, multilayer neural network with a hidden layer is shown in Fig 5.

The aim of training is to determine neuron weights $w_{i j}^{l}(l=1,2)$, denoted by superscript 1 and 2 for respectively the hidden and output layer, so that $y$ closely corresponding to $z$ is obtained at the output for the assigned input vector. Symbols $v_{j}$ and $y_{j}$ denote the output signals of respectively the hidden layer neurons $(j=1,2, \ldots K)$ and the output layer neurons $(j=1,2, \ldots M)$.

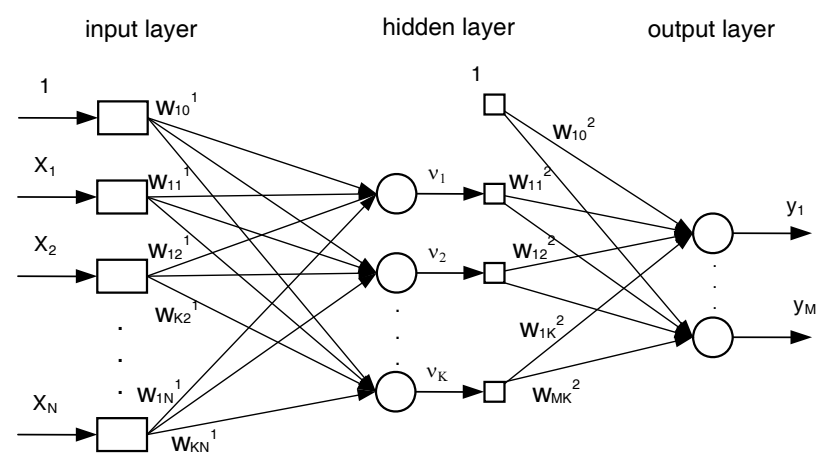

Fig 5. Model of error backpropagation, unidirectional twolayer neural network with one hidden layer [8, 10-13]

As the neural network is being trained one cannot tell in advance which parameters and modifications will yield the best results. This depends on the task which the neural network is to perform and on the set of training patterns. A multilayer neural network is trained iteratively until the lowest averaged error is obtained. The latter expresses a given neural network's degree of learning which is usually assessed by means of the root means square error (RMSE). If the set of training patterns is written as:

$$
U=\left\{(x, z)^{(\mathrm{p})} \mid p=1, \ldots, U\right\},
$$

where: $(x, z)^{(\mathrm{p})}-$ known input and output vectors of patterns $p$, and the testing set is written as:

$$
T=\left\{(x, z)^{(\mathrm{p})} \mid p=1, \ldots, T\right\} .
$$


a)

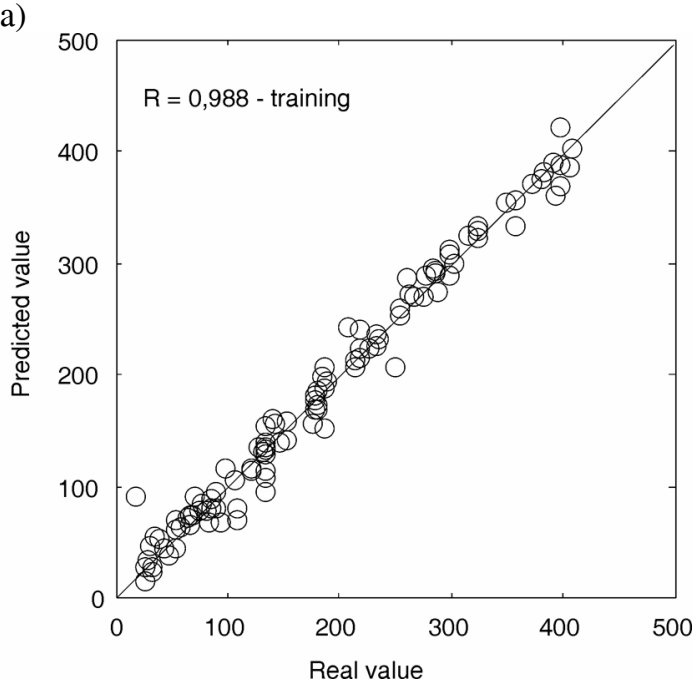

b)

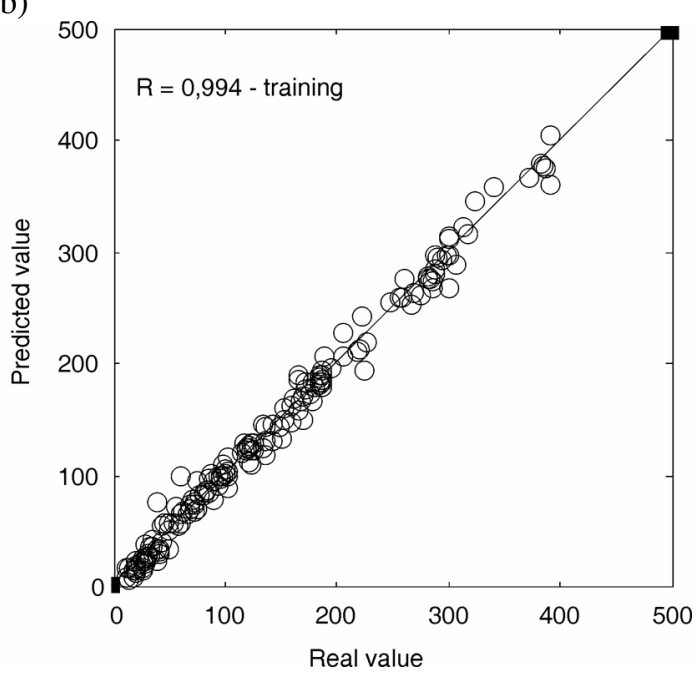

c)

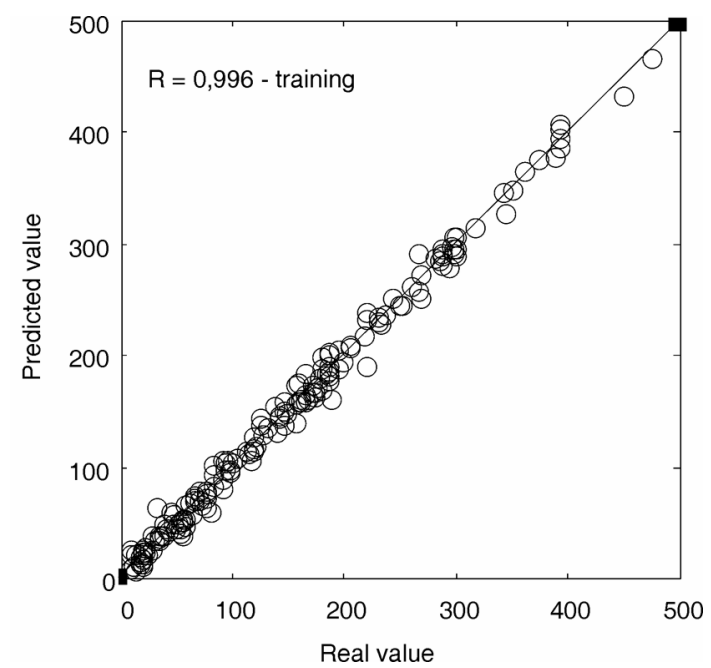

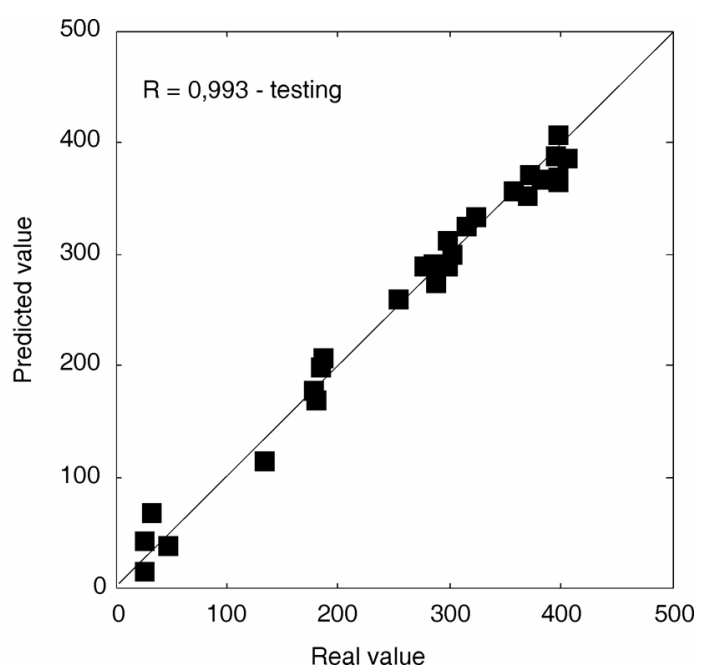
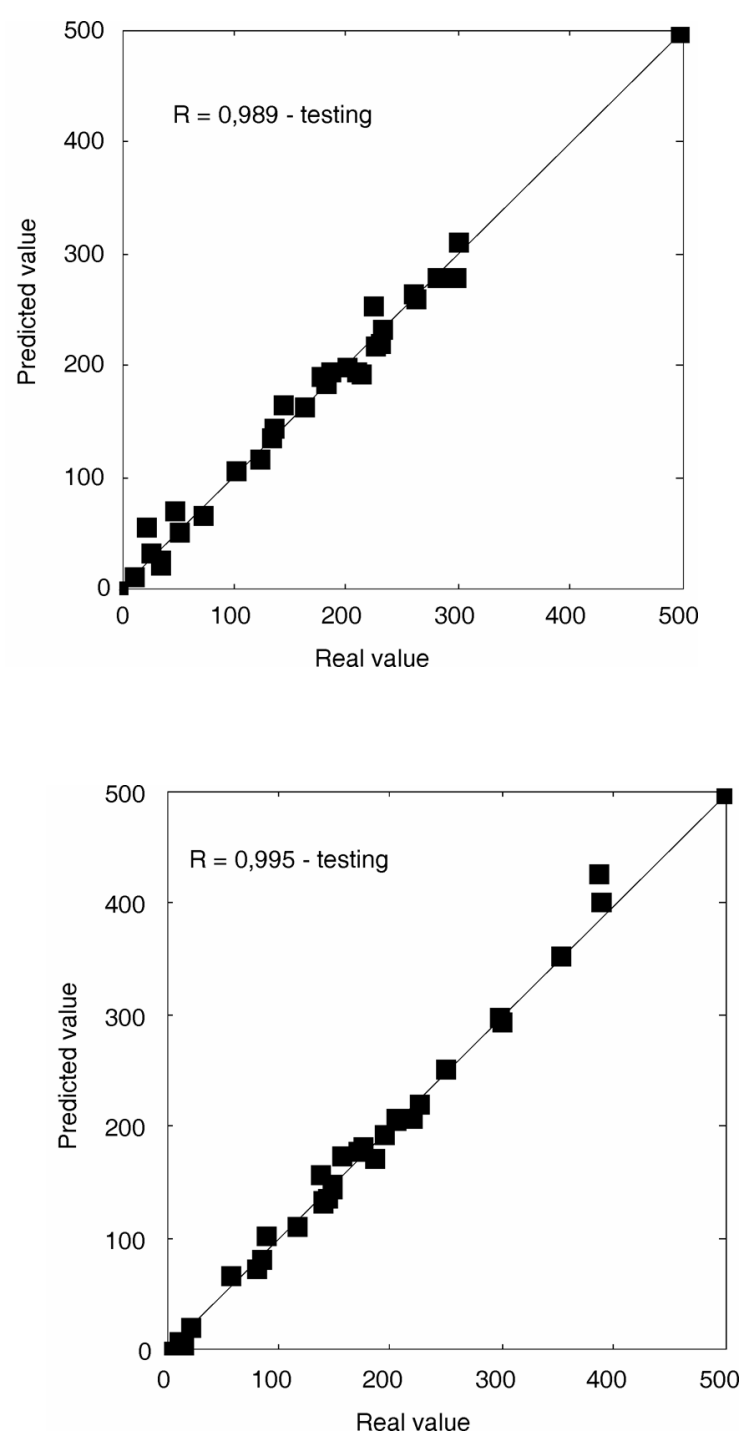

Figs 6. Relation between value yielded by model simulating operation of machinery system and value predicted by neural network (for training and testing sets) for productivity $W_{(N), S}$ and hauling distance of a) $\left.\left.2 \mathrm{~km}, \mathrm{~b}\right) 5 \mathrm{~km}, \mathrm{c}\right) 7 \mathrm{~km}$ 


$$
\operatorname{RMSE}(P)=\sqrt{\frac{1}{P} \sum_{p=1}^{P}\left(z_{i}^{(p)}-y_{i}^{(p)}\right)^{2}},
$$

where: $P=U, T$.

The process of training the neural network was repeated many times, introducing changes in:

- the number of hidden layers;

- the number of neurons in the hidden layers;

- the training coefficient;

a)

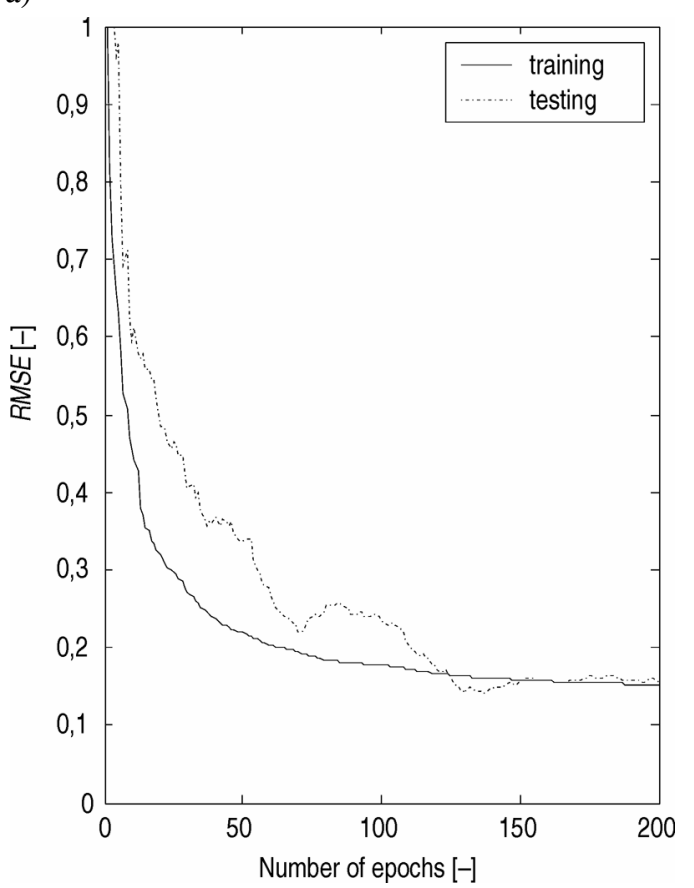

- the weights;

- the permissible error threshold.

Appropriate training algorithms, the number of hidden layers ( 1 to 3 ), the number of hidden layer neurons (6 to 14 ) and the number of epochs (5 to 5000) were determined experimentally, separately for each network. An epoch is understood as a single pass through the entire training set, followed by testing of the verification set during iterative training of a neural network.

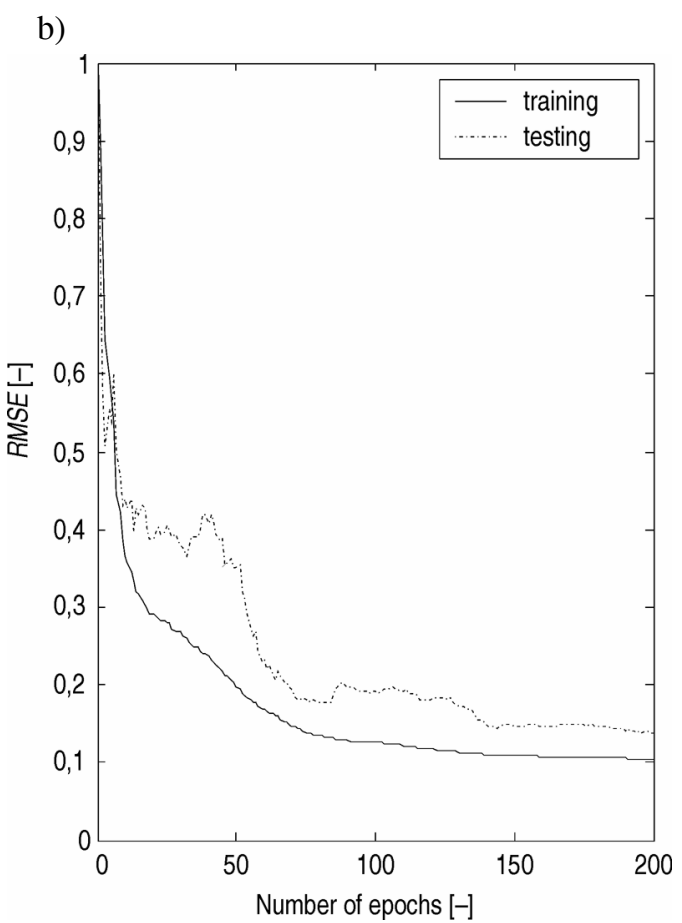

c)

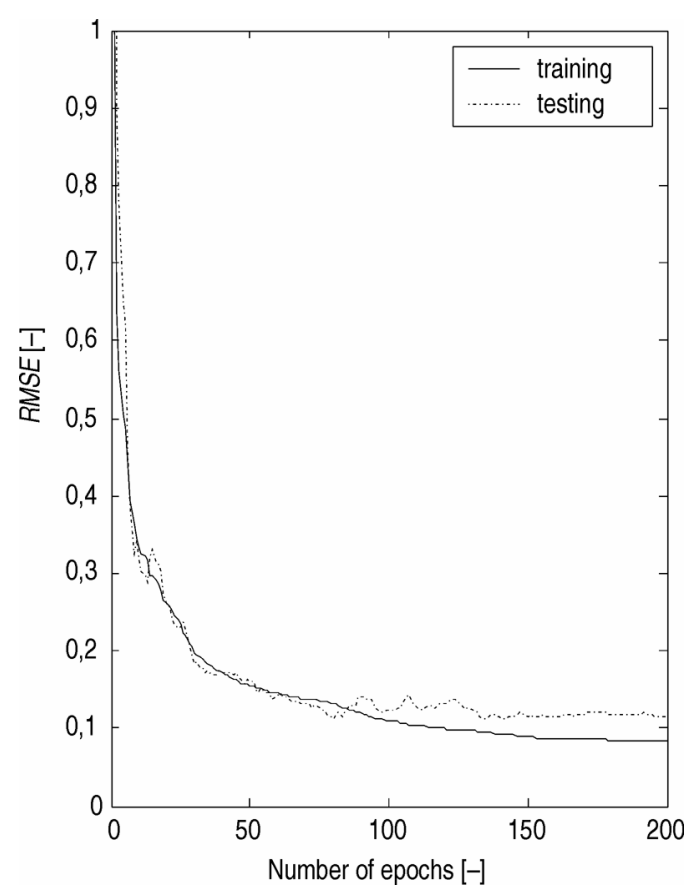

Fig 7. Neural network training and testing RMSE versus number of epochs for productivity $W_{(N), S}$ and hauling distance of a) $\left.2 \mathrm{~km}, \mathrm{~b}\right) 5 \mathrm{~km}$, c) $7 \mathrm{~km}$ 
One should note that 200 patterns (170 for training and 30 for testing) were used for each neural network. During network modelling stop criteria were applied to the training process. A network was considered well trained when:

- the values of the training and testing errors were the same or similar,

- the number of epochs at the assumed error value was the smallest,

- the correlation coefficient for data mapping was close to 1 ,

- the training and testing errors were below $15 \%$,

- the standard deviation was below $12 \%$.

\section{Network training and testing results}

Fig 6 illustrates the relation between the value yielded by the model simulating the operation of the machinery system and the value predicted by the BPNNCGB neural network for a hauling distance of 2, 5 and $7 \mathrm{~km}$. The results prove that the BPNN-CGB neural network correctly maps the training data and correctly identifies the testing data - as evidenced by the location of the points close to the centre line (corresponding to the ideal mapping) and by the fact that very high values of correlation coefficient $R$ (see Figs 6) were obtained for both training and testing.

Table 3. Correlation coefficient and RMSE values for BPNNCGB for identifying productivity $W_{(N), S}$ at specified hauling distances

\begin{tabular}{c|c|c|c|c}
\hline $\begin{array}{c}\text { Distance } \\
\text { in km }\end{array}$ & \multicolumn{2}{|c|}{$\begin{array}{c}\text { Correlation coeffi- } \\
\text { cient } R \\
{[-]}\end{array}$} & \multicolumn{2}{c}{$\begin{array}{c}\text { Root mean square } \\
\text { error } R M S E \\
{[-]}\end{array}$} \\
\cline { 2 - 5 } & training & testing & training & testing \\
\hline 1 & 0,993 & 0,993 & 0,0128 & 0,0148 \\
\hline 2 & 0,988 & 0,993 & 0,0232 & 0,0240 \\
\hline 3 & 0,992 & 0,989 & 0,0159 & 0,0232 \\
\hline 5 & 0,994 & 0,989 & 0,0109 & 0,0188 \\
\hline 7 & 0,996 & 0,995 & 0,0070 & 0,0132 \\
\hline
\end{tabular}

Fig 7 shows graphs of the training and testing $R M S E S$ versus the number of epochs for the adopted neural network for respectively productivity $W_{(N), S}$ at a hauling distance of 2,5 and $7 \mathrm{~km}$. It follows from the figures that $R M S E$ rapidly decreases with the increasing number of epochs.

The correlation coefficient and RMSE values for the BPNN-CGB network for identifying productivity $W_{(N) S}$ at the particular hauling distances are compiled in Table 3.

\section{Conclusion}

The results presented confirm the suitability of unidirectional multilayer error back propagation neural networks with a conjugate gradient algorithm (BPNN-CGB) for predicting the productivity $\left(W_{(N), S}\right)$ of systems of collaborating earthmoving machines, as evidenced by the low network training and testing RMSE values and the high values of correlation coefficient $R$ for testing. This has been demonstrated for different configurations of machines operating in a system consisting of $c$ excavators and $N$ trucks at output hauling distances of 1, 2, 3, 5 and $7 \mathrm{~km}$.

From the above one can draw the conclusion that having a set of such data as: hauler capacity $P_{j t}$, excavator bucket capacity $b_{k}$, hauling distance $L$, road class $K_{d}$, number of excavators $c$ and the number of haulers $(N)$ operating in the system and the corresponding (to this set) productivities obtained for different hauling distances, one can train neural networks and then use them to reliably predict productivity $W_{(N .), S}$ in the design of earthwork processes in the construction industry.

\section{References}

1. FILIPOWICZ, B. Stochastic models in operations research. Warsaw: WNT, 1996. 328 p. (in Polish).

2. GROSS, D. and CARL, M. H. Fundamentals of queuing theory. Wiley, 1998. $439 \mathrm{p}$.

3. GONNZALEZ-QUEVEDO, A. A.; ABOURIZK, S. M.; ISELEY, D. T. and HALPIN, D. W. Methodologies in construction. ASCE Journal of Construction Engineering and Management, 119 (3), 1993, p. 573-589.

4. HOLA, B. and MROZOWICZ, J. Modelling of construction processes having a random character. Wroclaw: DWE, 2003. 279 p. (in Polish).

5. KAPLIŃSKI, O. Modelling of construction processes. A managerial approach. Studies on Civil Engineering (Studia z zakresu inżynierii), No 43, Polish Academy of Sciences, Warsaw, 1997, p. 1-175.

6. MARITAS, D. G. and XIROCOSTAS, D. A. The $M / E_{k} / r$ machine interference model. European Journal of Operational Research, 1 (2), 1977, p. 112-123.

7. SMITH, S. D.; OBSBORNE, J. R. and FORDE, M. C. Analysis of earth-moving systems using discrete-event simulation. ASCE Journal of Construction Engineering and Management, 121 (4), 1995, p. 388-396.

8. FAUSETT, L. Fundamentals of neural networks - architectures, algorithms and application. Prentice Hall Inc., Englewood Cliffs, New Jersey, 1994. 461 p.

9. HAYKIN, S. Neural networks on comprehensive foundation. MacMillan Pub. Co., New York, 1999. 842 p.

10. HOŁA, J. and SCHABOWICZ, K. Application of artificial neural networks to determine concrete compressive strength based on non-destructive tests. Journal of Civil Engineering and Management, 11 (1), 2005, p. 23-32.

11. HOŁA, J. and SCHABOWICZ, K. Methodology of the neural identification of the strength of concrete. ACI Materials Journal, 102 (6), 2005, p. 459-464.

12. HOŁA, J. and SCHABOWICZ, K. New technique of nondestructive assessment of concrete strength using artificial intelligence. NDT \& E International, 38 (4), 2005, p. 251-259.

13. SCHABOWICZ, K. Neural networks in the NDT identification of the strength of concrete. Archives of Civil Engineering, 51 (3), 2005, p. 371-382.

14. ADELI, H. Neural networks in civil engineering: 19892000. Computer-aided Civil and Infrastructure Engineering, 16 (2), 2001, p. 126-142. 
15. HAJELA, P. and BERKE, L. Neural networks in structural analysis and design - an overview. Computing Systems in Engineering, 3 (1-4), 1992, p. 525-538.

16. OISHI, A.; YAMADA, K.; YOSHIMURA, S. and YAGAWA, G. Quantitative nondestructive evaluation with ultrasonic method using neural networks and computational mechanics. Computational Mechanics, 15 (6), 1995, p. 521-533.

17. WILIAMS, T. P.; KHAJURIA, A. and BALAGURU, P. Neural network for predicting concrete strength. In Proc of the 8th National Conference on Computing in Civil Engineering, Dallas, June 7-9, 1992. Ed. B. J. Goodno and J. R. Wright, ASCE, New York, 1992, p. 1082-1088.

18. KAVEH, A. and KHALEGI, A. Prediction of strength for concrete specimens using artificial neural networks. In Advances in Engineering Computational Technology. Ed. B. H. V. Topping, Civil-Comp Press, Edinburgh, 1998, p. $165-171$.

19. WASZCZYSZYN, Z. Neural networks in structural engineering: some recent result and prospects for applications. In Proc of 1st Asian-Pacific Congress Computational Mechanics - New Frontiers for New Millennium, Sydney, 20-23 Nov, 2001. Ed. S. Valliappan and N. Khalili. Elsevier, Amsterdam, 2001, p. 1311-1320.

20. BOUSSABAINE, A. H. The use of artificial neural networks in construction management: a review. Construction Management \& Economics, 14(5), 1996, p. 427-436.

21. HEGAZY, T and AYED, A. Neural network model for parametric cost estimation of highway projects. ASCE Journal of Construction Engineering and Management, 124 (3), 1998, p. 210-218.

22. SHI, J. J. A neural network based system for predicting earthmoving production. Construction Management \& Economics, 17 (4), 1999, p. 463-471.

23. TAM, C. M., TONG, T. K. L. and TSE, S. L. Artificial neural networks model for predicting excavator productivity. Engineering, Construction \& Architectural Management, 9 (5-6), 2002, p. 446-452.

\section{Notation}

\begin{tabular}{|c|c|c|}
\hline \multicolumn{3}{|c|}{ Symbols used in this paper: } \\
\hline$b_{k}$ & $=$ & excavator bucket capacity \\
\hline$c$ & $=$ & the number of excavators \\
\hline$p_{k}$ & $=$ & $\begin{array}{l}\text { the probability that there are } \mathrm{k} \text { arrivals } \\
\text { in the system }\end{array}$ \\
\hline$p_{o}$ & $=$ & $\begin{array}{l}\text { the probability that there are no arri- } \\
\text { vals in the system }\end{array}$ \\
\hline$t_{i}$ & $=$ & time instant $\mathrm{i}$ \\
\hline$u_{i}$ & $=$ & network inputs \\
\hline$w_{i j}$ & $=$ & weights of synaptic connections \\
\hline$x_{i}$ & $=$ & $\begin{array}{l}\text { neural network input vector compo- } \\
\text { nents }\end{array}$ \\
\hline$y_{i}$ & $=$ & $\begin{array}{l}\text { neural network output vector compo- } \\
\text { nents }\end{array}$ \\
\hline$z_{i}$ & $=$ & assigned neural network output vector \\
\hline FIFO & $=$ & queuing rule: first in, first out \\
\hline$K_{d}$ & $=$ & the kind of road surface \\
\hline$M$ & $=$ & exponential distribution \\
\hline MSS/QS & $=$ & mass service system/queuing system \\
\hline$N$ & $=$ & the number of haulers \\
\hline$P$ & $=$ & the number of samples in the database \\
\hline$P_{j t}$ & $=$ & hauler loading platform capacity \\
\hline$R$ & $=$ & correlation coefficient \\
\hline RMSE & $=$ & root mean square error \\
\hline$S_{i}$ & $=$ & system state at instant $\mathrm{i}$ \\
\hline$S S_{i}$ & $=$ & service station denotation \\
\hline$T$ & $=$ & testing set, \\
\hline$T$ & $=$ & time \\
\hline$U$ & $=$ & training set, \\
\hline$W_{(N)}$ & $=$ & productivity \\
\hline$W_{(N), S}$ & $=$ & $\begin{array}{l}\text { productivity determined by neural } \\
\text { network }\end{array}$ \\
\hline $\mathrm{WP}_{(\mathrm{A})}$ & $=$ & excavator downtime coefficient \\
\hline$X_{0}$ & $=$ & bias (threshold value), \\
\hline$Z G_{i}$ & $=$ & arrival denotation \\
\hline$\lambda$ & $=$ & arrivals entry distribution parameter \\
\hline$\mu$ & $=$ & the average service rate \\
\hline
\end{tabular}

\section{MATEMATINIS-NEURONINIS MODELIS ŽEMĖS DARBŲ MAŠINŲ NAŠUMUI VERTINTI}

\section{K. Schabowicz, B. Hola}

Santrauka

Daugelyje statybos procesų naudojamos tarpusavyje susijusios statybinès mašinos, suformuojančios technologines sistemas. Pavyzdžiui, žemės darbams vienu metu taikomi ekskavatoriai ir savivarčiai. Pagrindinis statybinių mašinų rodiklis yra našumas. Straipsnyje pateikiamos žemės darbų mašinų sistemos, sudarytos iš $c$ ekskavatorių ir $N$ savivarčių, našumo vertinimo rezultatai. Našumas vertintas, taikant dirbtinius neuroninius tinklus. Eksperimentiškai apskaičiuotos našumo reikšmės gali būti panaudotos sudarant žemės darbų projektus. Turint žemės darbų mašinų sistemos techninių parametrų duomenų bazę bei tam tikrus našumus, esant skirtingiems grunto vežimo atstumams, iš pradžių mokomi dirbtiniai neuroniniai tinklai, o vėliau jie naudojami patikimam darbo našumui prognozuoti.

Reikšminiai žodžiai: žemès darbai, neuroniniai tinklai, aptarnavimo teorija, statybos mašinų sistemos, statybos pramone.

Krzysztof Zbigniew SCHABOWICZ. PhD, Eng, obtained his diploma in civil engineering at Wroclaw University of Technology, Poland in 1996. Working at WUT, Institute of Building Engineering he has spent over 10 years in the field of research on strengthening concrete, non-destructive tests and artificial intelligence (artificial neural networks). Member of PZITB, PSMB.

Bozena HOLA. PhD, Eng, obtained her diploma in civil engineering at Wroclaw University of Technology, Poland, 1976. Working at WUT, Institute of Building Engineering, she has spent over 20 years in the field of research on modelling the construction processes, a managerial approach, safety and health protection at work. Member of PZITB. 